\title{
Effect of colistin and tylosin used as feed additives on the performance, diarrhea incidence, and immune response of nursery pigs
}

\section{Efeito do uso da colistina e da tilosina como aditivos alimentares sobre o desempenho, incidência de diarreia e resposta imune de leitões na fase de creche}

\author{
Kelly Mazutti ${ }^{*}$; Leandro Batista Costa $^{2}$; Lígia Valéria Nascimento ${ }^{3}$; \\ Tobias Fernandes Filho ${ }^{4}$; Breno Castello Branco Beirão"; \\ Pedro Celso Machado Júnior ${ }^{5}$; Alex Maiorka ${ }^{6}$
}

\begin{abstract}
For the last several decades, antimicrobial compounds have been used as feed additives to promote piglet growth at weaning, through the prevention of subclinical and clinical disease. However, few studies have assessed the influence of these antibiotics on the immune response of nursery pigs, as well as the relation between performance, health, and immunity of animals that receive feed additives. Therefore, the present study aimed to evaluate the effects of colistin and tylosin when used as feed additives on the performance, incidence of diarrhea, and immune response of nursery pigs. In this study, 72 weaned pigs (average age, 28 days) were allotted into one of three treatment groups: a control group (feed with no antibiotics), tylosin group (feed containing $22 \mathrm{ppm}$ tylosin), and colistin group (feed containing $20 \mathrm{ppm}$ colistin). Weekly, during a five week period, the average daily feed intake, average daily gain, and feed conversion ratio of the pigs were evaluated. Stools were scored daily, in accordance with a fecal texture scale. Blood samples were collected on the day of housing (d0) and on $\mathrm{d} 7, \mathrm{~d} 21, \mathrm{~d} 28$, and $\mathrm{d} 35$ for immune cell phenotyping. The results of this study showed that piglets in both the colistin and tylosin groups exhibited a significantly higher average daily feed intake, resulting in a higher body weight at the end of the experimental period (d35) when compared with piglets from the control group. Colistin and tylosin also significantly reduced the incidence of diarrhea. Colistin and tylosin modulated the piglets' immune responses, particularly on $\mathrm{d} 28$, by changing the percentage of circulating B lymphocytes, $\mathrm{CD} 4^{+} \mathrm{CD} 8^{+} \mathrm{T}$ cells, and the $\mathrm{CD} 4: \mathrm{CD} 8$ ratio.
\end{abstract}

Key words: Antibiotics. Cell-mediated immunity. Growth promoters. Pigs. Weaning.

1 Prof ${ }^{\mathrm{a}}$, Assistente III, Curso de Medicina Veterinária, Escola de Ciências Agrária e Medicina Veterinária, Pontifícia Universidade Católica do Paraná, PUCPR, Curitiba, PR, Brasil. E-mail: kelly.mazutti@pucpr.br

2 Prof., Adjunto, Programa de Pós-Graduação em Ciência Animal, PUCPR, Curitiba, PR, Brasil. E-mail: batista.leandro@pucpr. br

3 M.e em Ciência Animal, Programa de Pós-Graduação em Ciência Animal, PUCPR, Curitiba, PR, Brasil. E-mail: ligiavaleria. nascimento@gmail.com

4 Pesquisadores, Imunova Análises Biológicas Ltda, Curitiba, PR, Brasil. E-mail: tobias.filho@gmail.com; brenocbb@yahoo. com.br

5 Pesquisador, Impextraco Latin America, Curitiba, PR, Brasil. E-mail: pedroborck@gmail.com

6 Prof., Associado, Departamento de Zootecnia, Universidade Federal do Paraná, UFPR, Curitiba, PR, Brasil. E-mail: amaiorka@ ufpr.br

Author for correspondence 


\title{
Resumo
}

\begin{abstract}
Nas últimas décadas, os compostos antimicrobianos têm sido utilizados como aditivos alimentares para promover o crescimento de leitões ao desmame, por meio da prevenção de doenças clínicas e subclínicas. No entanto, poucos estudos avaliaram a influência destes antibióticos sobre a resposta imune de leitões na fase de creche, bem como a relação entre o desempenho, a saúde e a imunidade dos animais com o uso destes aditivos. Sendo assim, o presente estudo teve como objetivo avaliar o efeito da colistina e da tilosina como aditivos na alimentação sobre o desempenho, incidência de diarreia e resposta imune de leitões na fase de creche. Para isso, foram utilizados 72 suínos recém-desmamados, com 28 dias de idade em media, divididos em três tratamentos: grupo controle (ração sem antibiótico), grupo tilosina (ração com 22 ppm de tilosina), grupo colistina (ração com 20 ppm de colistina). Semanalmente, durante cinco semanas, foi analisado o consumo deração diário, o ganho de peso diário e a conversão alimentar dos leitões. As fezes foram avaliadas diariamente, com a atribuição de escores relacionados à sua consistência. Amostras de sangue foram coletadas no momento do alojamento (d0) e aos d7, d21, d28 e d35, sendo submetidas à técnica de citometria de fluxo. Os resultados demonstraram que tanto o grupo colistina como o grupo tilosina promoveram aumento significativo no consumo de ração diário, o que se refletiu em maior peso ao final do estudo (d35), quando comparados ao grupo controle. A colistina e a tilosina também promoveram redução significativa na incidência de diarreia. A colistina e a tilosina modularam a atividade imune, principalmente aos 28 dias, alterando a porcentagem circulante de linfócitos B, células CD4+CD8+ e da razão entre CD4 e CD8.
\end{abstract}

Palavras-chave: Antibióticos. Desmame. Imunidade celular. Promotores de crescimento. Suínos.

\section{Introduction}

In industrial pig production, animals often experience stressful situations that may negatively affect their intestinal microbiota, allowing for the development of gastrointestinal infections. The time of weaning and the post-weaning period both demand a considerable effort by pig producers to reduce the stress experienced by piglets (GAGGìA et al., 2010). Those periods are characterized by a sudden - albeit transitional - reduction in feed intake, which negatively affects a piglet's growth potential, as well as increases their susceptibility to intestinal disorders and infections, resulting in diarrhea (MODESTO et al., 2009; HEO et al., 2013).

On most pig farms, piglets are weaned between 21 and 28 days of age (LALLÈS et al., 2007; MARCOLLA; RIBEIRO, 2015). This period corresponds with the transition from passive to active immunity, a time characterized by a dramatic reduction of blood IgG levels (BAUER et al., 2006), which increases an animal's susceptibility to infections. In addition, at the time of weaning, piglets experience several stressful situations, such as a sudden change in the composition and physical form of their diets (nutritional stress), separation from the sow and the establishment of a new social hierarchy when different litters are mixed within nursery pens (social stress), as well as adapting to a new environment (environmental and handling stress) (MODESTO et al., 2009; PLUSKE, 2013; MARTINEZ et al., 2014). Both the compromised immune status and the stresses to which the piglets are exposed to favor the replication of pathogens in the intestines, which may result in diarrhea (YUAN et al., 2006; HEO et al., 2013; PLUSKE, 2013). Thus, it is common to include antimicrobials in the feed, used as performance enhancing additives, for piglets in the post-weaning phase (CROMWELL, 2002; HEO et al., 2013; PLUSKE, 2013).

Feed additives are defined as substances that are not nutrients that may be added to an animal's feed (PALERMO NETO, 2001). The main functions of feed additives are to increase productivity, to reduce mortality, and to prevent infections and feed spoilage (UTIYAMA et al., 2006). Antibiotics have been used as feed additives in livestock diets since 1949 (JUKES, 1972), particularly during 
critical production phases, such as the weaning period in pigs. The efficiency of antibiotics in increasing growth rate, improving feed utilization, and reducing mortality from clinical disease is well documented (CROMWELL, 2002).

Colistin and tylosin are commonly used as feed additives in pig production. Colistin belongs to the polymyxin group of bactericidal antibiotics (SPINOSA, 2006a; MENDES; BURDMANN, 2009). It is produced by Bacillus colistinus (MENDES; BURDMANN, 2009) and acts against several Gram-negative microorganisms, including Escherichia coli, Salmonella spp., and Pseudomonas spp. (ZUANON et al., 1998). Polymyxins bind to phosphate radicals on the cell membranes of bacteria, which disrupts the cell membrane, resulting in a loss of the membrane's selectivity and allows for the leakage of small particles from the bacterial cytoplasm and eventually causing cell death. Tylosin is a bacteriostatic macrolide antibiotic isolated from Streptomyces fradiae. It inhibits microbial protein synthesis by interfering with the base of the translocation between $\mathrm{A}$ and $\mathrm{P}$ sites of the 50S unit of the bacterial ribosome, preventing tRNA translocation and inhibiting the enzyme peptidyl transferase, thereby preventing the elongation of the peptide chain (SPINOSA, 2006b).

The use of colistin and tylosin as antimicrobial feed additives is authorized in Brazil (MAPA, 2014). While some authors observed better performance in pigs fed colistin (LOVATTO et al., 2005; COSTA et al., 2007) and tylosin (YAN et al., 2011; GAVIOLI, 2013) as in-feed additives, others did not detect any performance differences in pigs fed either colistin (GOMES et al., 1981) or tylosin (VAN LUNEN, 2003), demonstrating the need of further studies on the efficacy of these antimicrobials. In addition, no literature reports were found that studied the effect of colistin and tylosin on cell-mediated immunity of nursery pigs, or the relation between performance, health, and immunity of animals that received these feed additives. Therefore, this study aimed at evaluating the effects of colistin and tylosin when used as feed additives on the performance, incidence of diarrhea, and immune response of nursery pigs.

\section{Materials and Methods}

\section{Animals and facilities}

Seventy-two recently weaned piglets, with an average age of 28 days, were allotted into one of three treatment groups with eight replicates of three animals each, according to a randomized block experimental design. The duration of the experimental period was five weeks, starting at the time of housing.

Pigs were housed in suspended nursery pens $(1.2 \times 1.6 \mathrm{~m})$, with fully-slatted plastic flooring, and were offered feed and water ad libitum during the entire experimental period. Pigs were handled according to the practices recommended by the Canadian Council on Animal Care (CCAC, 1993). The experimental procedures were approved by the Ethics Committee on the Use of Animals of Pontifical University Catholic of Parana (PUCPR), under project number 792 .

\section{Diets}

The feeding period was divided into a pre-starter phase (first two weeks of the experiment) and a starter phase (last three weeks of the experiment). A basal diet was formulated for each feeding phase (Table 1) to meet or exceed the nutritional requirements of nursery pigs as determined by the National Research Council (NRC, 2012). Calculated nutritional values from pre-starter and starter diets can be observed in table 2. The three experimental diets consisted of: the basal diet without antibiotics (control group), the basal diet with the addition of $20 \mathrm{ppm}$ of colistin (colistin group), and the basal diet with the addition of $22 \mathrm{ppm}$ of tylosin (tylosin group). 


\section{Performance parameters}

Piglets were weighed at the time of housing and were then evenly distributed into the experimental treatment groups according to their body weight. Average daily feed intake (ADFI), average daily gain (ADG) and feed conversion ratio (FCR) were recorded weekly.

Table 1. Composition of the pre-starter and starter diets used in the post-weaning phases.

\begin{tabular}{lcc}
\hline \multicolumn{1}{c}{ Ingredient } & Pre Starter $(\mathrm{g} / \mathrm{kg})$ & Starter $(\mathrm{g} / \mathrm{kg})$ \\
\hline Corn & 435.9 & 513.0 \\
Soybean meal & 260.0 & 250.0 \\
Premix ${ }^{1}$ & 276.8 & 202.7 \\
Soybean oil & 15.0 & 17.0 \\
Limestone & 9.0 & 9.0 \\
Dicalcium phosphate & - & 3.0 \\
L-Lysine & 2.0 & 3.8 \\
DL-Methionine & 0.4 & 0.5 \\
Threonine & 0.9 & 1.0 \\
\hline TOTAL & 1000 & 1000 \\
\hline
\end{tabular}

${ }^{1}$ Guaranteed levels per $\mathrm{kg}$ of product: folic acid (min) $2.40 \mathrm{mg}$; pantothenic acid (min) $88.00 \mathrm{mg}$; biotin (min) $0.40 \mathrm{mg}$; calcium $16.44 \mathrm{~g}$; copper (min) $800 \mathrm{mg}$; ether extract (min) $75.60 \mathrm{~g}$; iron (min) $800 \mathrm{mg}$; crude fiber $5.70 \mathrm{~g}$; phosphorus (min) $14.93 \mathrm{~g}$; iodine ( $\mathrm{min}) 7.2 \mathrm{mg}$; lysine (min) $16.95 \mathrm{~g}$; manganese (min) $220 \mathrm{mg}$; mineral matter (max) $119.35 \mathrm{~g}$; methionine (min) $700 \mathrm{mg}$; niacin $(\mathrm{min}) 140.00 \mathrm{mg}$; crude protein $(\mathrm{min}) 155.72 \mathrm{~g}$; selenium $(\mathrm{min}) 1.20 \mathrm{mg}$; sodium (min) $12.22 \mathrm{~g}$; threonine (min) $10.36 \mathrm{~g}$; tryptophan (min) $2.930 \mathrm{mg}$; wetness (max) $62.30 \mathrm{~g}$; vitamin A (min) 50,000.00 IU; vitamin B1 (min) $12 \mathrm{mg}$; vitamin B12 (min) $100 \mu \mathrm{g}$; vitamin B2 (min) $20 \mathrm{mg}$; vitamin B6 (min) 12 mg; vitamin D3 (min) 10,000.00 IU; vitamin E (min) 160.00 IU; vitamin K3 (min) $12.00 \mathrm{mg}$; and zinc $(\mathrm{min}) 500.00 \mathrm{mg}$.

Table 2. Calculated nutritional values of the pre-starter and starter diets used in the post-weaning phases.

\begin{tabular}{lcc}
\hline \multicolumn{1}{c}{ Ingredient } & Pre-starter & Starter \\
\hline Crude protein (\%) & 19.54 & 18.53 \\
Crude fat (\%) & 2.29 & 2.33 \\
Lactose (\%) & 6.03 & 4.42 \\
Crude fiber (\%) & 0.87 & 0.82 \\
Calcium (\%) & 0.68 & 0.63 \\
Phosphorus (\%) & 0.46 & 0.41 \\
Sodium (\%) & 0.34 & 0.25 \\
Chlorine (\%) & 1.49 & 1.54 \\
Lysine (\%) & 0.44 & 0.4 \\
Methionine+Cysteine (\%) & 0.74 & 0.69 \\
Threonine (\%) & 0.25 & 0.23 \\
Choline (\%) & 0.89 & 0.83 \\
Metabolizable Energy (kcal/Kg) & 3341.5 & 3335.06 \\
\hline
\end{tabular}




\section{Diarrhea incidence}

Pigs were inspected daily in the morning to monitor the fecal score of all pens, and the fecal texture was scored according to a 0-3 scale where 0 $=$ normal stools, $1=$ soft stools, $2=$ slurry stools, and 3 = watery stools. Scores 0 and 1 were considered normal stools, and scores 2 and 3 were considered diarrhea. The evaluation of the incidence of diarrhea was carried out by comparing the number of stools with scores of 2 and 3 between different treatment groups.

\section{Immune cell profile}

In order to evaluate the possible effects of colistin and tylosin on the cellular immune response of piglets, blood immune cells were phenotyped. Blood samples were collected from one individual per replicate at the time of housing $(\mathrm{d} 0)$, and at $\mathrm{d} 7$, $\mathrm{d} 21, \mathrm{~d} 28$, and $\mathrm{d} 35$ of the experiment.

Specific monoclonal antibodies including antiCD4 (conjugated with fluorescein isothiocyanate, FITC), anti-CD8 (conjugated with phycoerythrin, $\mathrm{PE}$ ), anti-monocyte+macrophage Kul-1 (conjugated with fluorescein isothiocyanate, FITC), and anti-B lymphocytes (conjugated with phycoerythrin, PE) were used. All antibodies were acquired from Southern Biotech (Birmingham, AL, USA), and were produced from mice.

Blood samples were processed according to Fernandes Filho et al. (2013) and analyzed in a flow cytometer (FACSCalibur, Becton Dickson, Franklin Lakes, NJ, USA). FITC fluorescence was detected in the FL1 channel (nm 530/30) and PE fluorescence in the FL2 channel (nm 585/42). At least 10,000 events were acquired based on the selection of the lymphocyte region on the cell size and complexity graph (FSC x SSC). Flow cytometry data were analyzed using the CellQuest Pro software (Becton Dickson, Franklin Lakes, NJ, USA).

\section{Statistical analysis}

Data were submitted for analysis of variance and means were compared by the LSD test, using the Statistix 8 statistical package (Analytical Software, Tallahassee, FL, USA).

Differences in fecal scores were evaluated with the Kruskall-Wallis test, followed by the Dunn's multiple comparison test.

Immune cell percentages were submitted for analysis of variance and means were compared by the test of Bonferroni. Graphs and statistical analyses were generated by the software GraphPad Prism (GraphPad Software, La Jolla, CA USA).

All statistical analyses were carried out at $\mathrm{p}<0.05$.

\section{Results and Discussion}

Average performance results of the control, tylosin, and colistin groups obtained for the first two experimental weeks (d14) and for the total experimental period (d35) are shown in Table 3 and 4 respectively.

Average daily feed intake (ADFI), average daily gain (ADG) and feed conversion ratio (FCR) were not influenced by the treatments during the first two experimental weeks. On d14, piglets in the tylosin and colistin groups were significantly heavier than those in the control group. 
Table 3. Average initial body weight (AW1), average daily feed intake (ADFI), average daily gain (ADG), feed conversion ratio (FCR), and body weight on day 14 post weaning (W14) of nursery pigs fed a basal diet without antibiotics (control group) or with $20 \mathrm{ppm}$ of colistin (colistin group) or with $22 \mathrm{ppm}$ of tylosin (tylosin group).

\begin{tabular}{cccccc}
\hline Treatments & $\begin{array}{c}\text { AW1 } \\
(\mathrm{kg})\end{array}$ & $\begin{array}{c}\text { ADFI } \\
(\mathrm{kg})\end{array}$ & $\begin{array}{c}\text { ADG } \\
(\mathrm{kg})\end{array}$ & FCR & $\begin{array}{c}\text { W14 } \\
(\mathrm{kg})\end{array}$ \\
\hline Control group & 5.92 & 0.447 & 0.302 & 1.50 & $10.19^{\mathrm{b}}$ \\
Tylosin group & 5.92 & 0.507 & 0.361 & 1.40 & $10.98^{\mathrm{a}}$ \\
Colistin group & 5.95 & 0.504 & 0.362 & 1.41 & $11.02^{\mathrm{a}}$ \\
\hline P value & 0.344 & 0.115 & 0.053 & 0.114 & 0.041 \\
Coefficient of variation & 0.86 & 12.39 & 14.96 & 7.07 & 6.10 \\
\hline
\end{tabular}

Different superscripts in the same column indicate significant differences by the LSD test $(\mathrm{p} \leq 0.05)$.

Table 4. Average daily feed intake (ADFI), average daily gain (ADG), feed conversion ratio (FCR), and body weight on day 35 post weaning (W35) of nursery pigs fed a basal diet without antibiotics (control group) or with $20 \mathrm{ppm}$ of colistin (colistin group) or with $22 \mathrm{ppm}$ of tylosin (tylosin group).

\begin{tabular}{ccccc}
\hline Treatments & $\begin{array}{c}\text { ADFI } \\
(\mathrm{kg})\end{array}$ & $\begin{array}{c}\text { ADG } \\
(\mathrm{kg})\end{array}$ & FCR & $\begin{array}{c}\text { W35 } \\
(\mathrm{kg})\end{array}$ \\
\hline Control group & $0.794^{\mathrm{b}}$ & 0.474 & 1.67 & $22.56^{\mathrm{b}}$ \\
Tylosin group & $0.880^{\mathrm{a}}$ & 0.525 & 1.67 & $24.30^{\mathrm{a}}$ \\
Colistin group & $0.885^{\mathrm{a}}$ & 0.520 & 1.70 & $24.24^{\mathrm{a}}$ \\
\hline P value & 0.035 & 0.069 & 0.635 & 0.050 \\
Coefficient of variation & 8.25 & 8.72 & 4.09 & 6.11 \\
\hline
\end{tabular}

Different superscripts in the same column indicate significant differences by the LSD test $(\mathrm{p} \leq 0.05)$.

The results presented in Table 4 show that the pigs in the tylosin and colistin groups averaged a significantly higher ADFI during the entire experimental period when compared with those in the control group. This feed intake difference resulted in a different body weight at the end of the experiment (d35), as the pigs in the tylosin and colistin groups were significantly heavier than the control animals. In addition, pigs in the tylosin and colistin groups also exhibited a higher, albeit not statistically significant ( $\mathrm{P}=0.069)$, average daily gain (ADG) during the total experimental period (d35) compared with those in the control group. The feed conversion ratio was not significantly different among treatments.

Tylosin is able to alter the intestinal microbiota, and its use in piglets is related to an improvement in animal performance, especially related to feed intake as observed in the present study, and feed conversion ratio (BOSI et al., 2011; YAN et al., 2011; KIM et al.,
2012; GAVIOLI, 2013). One mechanism that may explain this improved performance is an increase in the relative mass of lactobacilli in the intestinal tract when compared to enterogenic bacteria, owing to a significant decrease of the latter (COLLIER et al., 2003; BOSI et al., 2011). Therefore, because of the prevalence of lactobacilli within the small intestine, where the majority of nutrient absorption occurs, the alteration of these bacteria is a potentially important mechanism involved in antibioticinfluenced animal growth (COLLIER et al., 2003). Macrolides are known to be minimally effective against Gram-negative bacteria in the intestine because of the outer membrane permeability barrier of Gram-negative bacteria. The outer membrane cannot be easily penetrated by macrolides due to the increased molecular size of these antibiotics in relation to the size of the bacterial porin channels (NORCIA et al., 1999). Nevertheless, some enterobacteria strains have an incomplete 
lipopolysaccharide structure, permitting increased penetration by macrolides (NORCIA et al., 1999). There is also evidence that this class of antibiotics can directly interact with the immune response after induction by lipopolysaccharides; however, in that instance, macrophages and monocytes responded by decreasing the gene expression of various inflammatory cytokines (CAO et al., 2006). Thus, the positive action of tylosin on piglet growth and feed intake observed in the present study can result from the decreased costs of immune activation determined by the action on intestinal microflora or from the enhanced uptake and use of nutrients.

Gavioli (2013) carried out a study comparing the performance of growing pigs that were fed diets containing colistin (10 ppm), tylosin (40 ppm), or a symbiotic product, and found a higher average daily feed intake in pigs fed tylosin when compared to other treatments, but there were no significant differences in other evaluated performance parameters. Those authors report that the higher average daily feed intake in pigs fed tylosin compared to pigs fed colistin may be due to sensory characteristics of these antibiotics, as colistin incorporates a bitter taste to the feed, leading to a reduction in dietary intake. However, this reduction was not observed in our study. On the other hand, other authors did not observe any improvements in the performance of nursery pigs with the inclusion of tylosin in the feed (SILVA et al., 2007; HOLMAN; CHÉNIER, 2013).

The results obtained with colistin in the present study are consistent with the findings of Lovatto et al. (2005), who obtained a higher average daily feed intake and average daily gain when colistin was added to the diet of nursery pigs. Sbardella (2014) observed that the use of colistin as a feed additive (at $40 \mathrm{ppm}$ ) improved the final body weight, weight gain, and feed conversion ratio of nursery pigs. However, these authors did not find any effect of colistin on feed intake, in contrast to the findings of the present study.

How antibiotics, used as feed additives, increase performance is not clear, but possible mechanisms may include: a reduction in total bacterial load; suppression of pathogens; inhibition of endemic subclinical infection, thus reducing the metabolic costs of the (innate) immune system; reduction of growth-depressing metabolites (such as ammonia and bile degradation products) produced by microbes; reduction of microbial use of nutrients; enhancing the uptake and use of nutrients, because the intestinal wall in animals fed with feed additives is thinner; and direct modulation of the immune system (DIBNER; BUTTIN, 2002; HARDY, 2002; BUTAYE et al., 2003; DIBNER; RICHARDS, 2005; NIEWOLD, 2007). According Niewold (2007), antibiotics most likely work as growth promoters by inhibiting the production and excretion of catabolic mediators by intestinal inflammatory cells. Concomitant or subsequent changes in microflora are most likely the consequence of an altered condition of the intestinal wall. It is suggested that the use of antibiotics decreases the level of inflammation. Intestinal inflammation usually leads to an accumulation of inflammatory cells in the intestinal mucosa, leading to a thicker intestinal wall. The thinner intestinal wall observed when using antibiotics as feed additives is consistent with a reduction in inflammation because of the reduced influx and accumulation of inflammatory cells (LARSSON et al., 2006). Moreover, inflammation and cytokine release promotes catabolism of muscle tissue and loss of appetite (GRUYS et al., 2006), which additionally affects an animal's performance.

Torrallardona et al. (2003) compared spraydried plasma and colistin (300 ppm) as feed additives for weaned piglets and showed that both products improved performance. In particular, colistin improved ADG, ADFI, and FCR, which is in agreement with the results of the present study. Those authors also observed that colistin helped to maintain the integrity of the intestinal mucosa, as suggested by the lower small intestinal weight and longer intestinal villi of the pigs fed colistin. In addition, colistin reduced the number of enterococci in the cecum and of Escherichia coli both in the ileum and in the cecum. 
The incidence of diarrhea was lower in the tylosin and colistin groups when compared with the control group (Table 5), and can be observed by the ranked mean of scores 2 and 3, which were considered diarrhea. Post-weaning diarrhea syndrome is a multifactorial disease that affects piglets after weaning. It may cause considerable economic losses, as mortality may reach up to $10 \%$ of pigs, in addition to increasing the number of culls, delaying growth, and increasing medication costs. The disease is also known as post-weaning colibacillosis, because the main causative agents are enterotoxigenic strains of
Escherichia coli (THOMSSON et al., 2008; LIMA et al., 2009). Other pathogens, such as Lawsonia intracellularis, Salmonella typhimurium, and $S$. choleraesuis may also be present and cause enteritis, thereby making the diagnosis and treatment of this condition difficult (MORÉS; MORENO, 2007). It has been suggested that the high susceptibility of early-weaned piglets to enteric disorders is due to disruption in the establishment of a stable intestinal microbiota, thereby allowing pathogenic bacteria to flourish and cause disease (KONSTANTINOV et al., 2004, 2006).

Table 5. Fecal score of nursery pigs fed a basal diet without antibiotics (control group) or with $20 \mathrm{ppm}$ of colistin (colistin group) or with $22 \mathrm{ppm}$ of tylosin (tylosin group) obtained by daily visual inspection of the pens during the 35 days of experiment. Stools were scored daily according to a fecal texture scale, where $0=$ normal stools, $1=$ soft stools, 2 = slurry stools, or 3 = watery stools.

\begin{tabular}{|c|c|c|c|}
\hline \multirow[t]{2}{*}{ Fecal score } & \multicolumn{3}{|c|}{ Treatments } \\
\hline & Control group & Tylosin group & Colistin group \\
\hline 0 & 978 & 937 & 1090 \\
\hline 1 & 1081 & 1086 & 1088 \\
\hline$(0+1)^{\mathrm{a}}$ & (2059) & $(2023)$ & $(2178)$ \\
\hline 2 & 373 & 197 & 290 \\
\hline 3 & 182 & 48 & 102 \\
\hline$(2+3)^{b}$ & $(555)$ & $(245)$ & $(392)$ \\
\hline Weighted Mean & 0.9078 & $0.7160 *$ & $0.7680 *$ \\
\hline Rank Mean $^{3}$ (all scores) & 3940.29 & $3574.75^{*}$ & $3642.97 *$ \\
\hline Rank Mean ${ }^{c}$ (scores 2+3) & 625.95 & $547.27 *$ & $585.58^{*}$ \\
\hline
\end{tabular}

a Scores 0 and 1 were considered as normal, ${ }^{\mathrm{b}}$ Scores 2 and 3 were considered as diarrhea, ${ }^{\mathrm{c}}$ Means obtained by the Kruskal-Wallis test. * Indicates significant difference when compared with the control group (Dunn's multiple comparison test).

The maintenance of the integrity of the intestinal mucosa and the reduced Escherichia coli counts in the ileum and the cecum of weaning pigs with the use of colistin, proposed by Torrallardona et al. (2003), may explain the results concerning the incidence of diarrhea in the present experiment, in that diarrhea was significantly lower in the colistin group as compared with the control group (Table 5). Sbardella (2014) also found a lower incidence of diarrhea in nursery pigs fed colistin compared with the control animals. On the other hand, Luna et al. (2015) did not observe any influence of colistin dietary supplementation on the incidence of diarrhea in nursery piglets.
The reduction in the diarrhea incidence observed in the tylosin group (Table 5) may be due to the ability of this antimicrobial to alter the intestinal microflora, increasing the number of bacteria such as lactobacilli, as already mentioned (COLLIER et al., 2003; BOSI et al., 2011). Lactobacilli are the predominant lactic acid bacteria found in the pig intestine and constitute a major proportion of intestinal microbiota. As such, they are of particular importance to the maintenance of gut health. The presence and activity of lactobacilli have a stimulatory effect on both gut immunity and maturation, enhancing immune protection, and reducing gastrointestinal inflammatory responses 
(KIMURA et al., 1997; BLUM; SCHIFFRIN, 2003). They also display antimicrobial activities that are involved in host epithelial immunity, such as the reduction of colonic $\mathrm{pH}$ (through the production of lactic acid), protection against mucosal pathogen invasion, and production of bacteriocins (VARCOE et al., 2003; PUTAALA et al., 2010). Kim et al. (2012) suggested that the development of the 'mature' gut microbiota in swine is accelerated by the addition of tylosin, although the gut microbiota of untreated pigs eventually reaches this state as well. However, Bosi et al. (2011) did not observe any difference from tylosin dietary supplementation on the fecal score of nursery piglets.

Another possible reason for the variations in diarrhea incidence are changes in the immune profile of the piglets. The use of the additives had a marked effect on immune cell dynamics in peripheral blood. The results of the immune cell profiles are shown in the graphs below. No significant differences were observed in the percentages of circulating $\mathrm{CD}^{-}$ $\mathrm{CD}^{+} \mathrm{T}$ cells (Figure 1 ), circulating $\mathrm{CD} 4^{+} \mathrm{CD} 8$-cells (Figure 2), or macrophages (Figure 3).

Figure 1. Percentage of circulating $\mathrm{CD} 4 \mathrm{CD}^{+} \mathrm{T}$ cells in relation to peripheral blood mononuclear cells (PBMC). Nursery pigs were fed a basal diet without antibiotics (control) or with $20 \mathrm{ppm}$ of colistin or $22 \mathrm{ppm}$ of tylosin. Blood was collected for PBMC immune cell typing at the time of weaning (day 0) and 7, 21, 28, and 35 days later. The immunophenotype of PBMC was determined by flow cytometry.

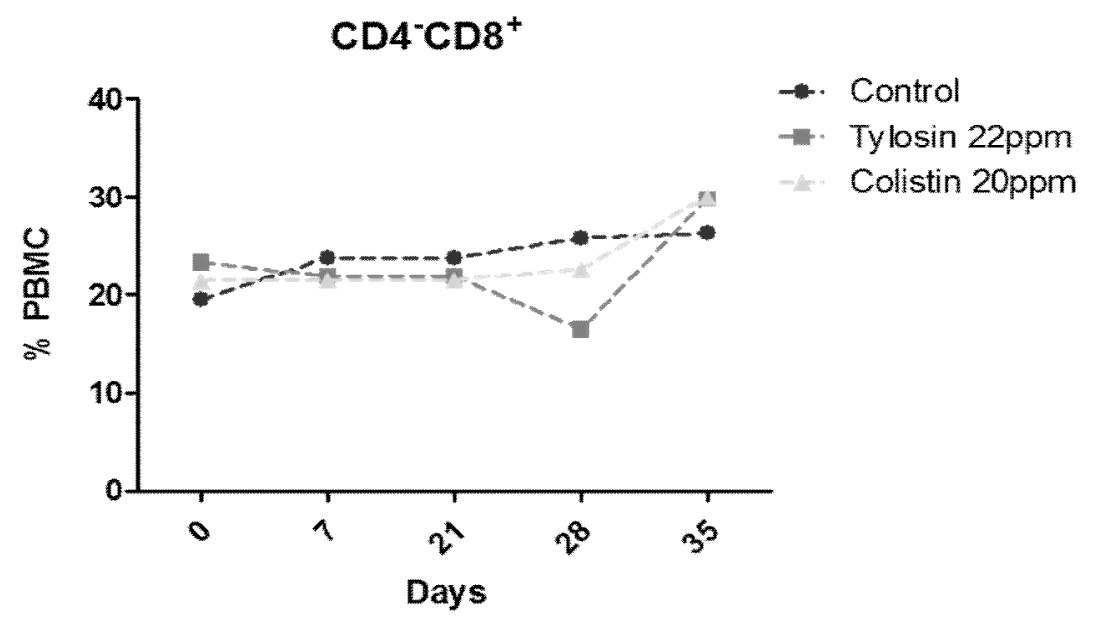

Statistical differences were observed only of intestinal lymphoid follicles. Therefore, it is on $\mathrm{d} 28$ for the populations of $\mathrm{B}$ cells (Figure 4), $\mathrm{CD}^{+} \mathrm{CD}^{+} \mathrm{T}$ cells (Figure 5) and for the CD4:CD8 ratio (Figure 6).

On $\mathrm{d} 28$, piglets from the colistin group exhibited lower circulating B-cell percentages compared to those from other groups (Figure 4). Bouskra et al. (2008) showed that colistin reduced the proliferation of individual lymphoid follicles within the intestine of mice. These authors found that the peptidoglycans of Gram-negative bacteria, which are the target of colistin, are essential for the development possible that the effect of colistin on Gram-negative bacteria modulated the percentage of circulating immune cells, particularly B cells, in the present experiment. This is consistent with the findings that piglets fed colistin had lower leukocyte percentages (particularly of lymphocytes) compared with those fed plant extracts (SAVOINI et al., 2002). The modulation of the intestinal microbiota may reduce the activity of cells, essentially by controlling the exposure to microbial stimuli, as shown with the administration of the antibiotic polymixin (GORIS et al., 1986). 
Figure 2. Percentage of circulating $\mathrm{CD} 4^{+} \mathrm{CD} 8^{-} \mathrm{T}$ cells in relation to peripheral blood mononuclear cells (PBMC). Nursery pigs were fed a basal diet without antibiotics (control) or with $20 \mathrm{ppm}$ of colistin or $22 \mathrm{ppm}$ of tylosin. Blood was collected for PBMC immune cell typing at the time of weaning (day 0) and 7, 21, 28, and 35 days later. The immunophenotype of PBMC was determined by flow cytometry.

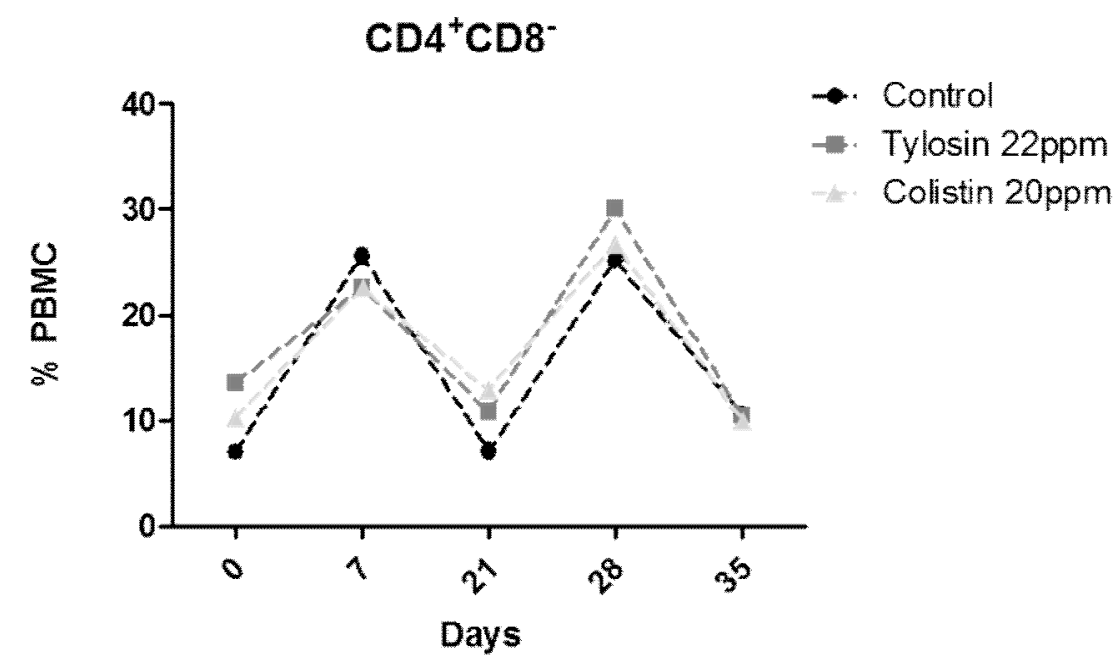

Figure 3. Percentage of circulating monocytes in relation to peripheral blood mononuclear cells (PBMC). Nursery pigs were fed a basal diet without antibiotics (control) or with $20 \mathrm{ppm}$ of colistin or $22 \mathrm{ppm}$ of tylosin. Blood was collected for PBMC immune cell typing at the time of weaning (day 0 ) and 7, 21, 28, and 35 days later. The immunophenotype of PBMC was determined by flow cytometry.

\section{Monocytes}

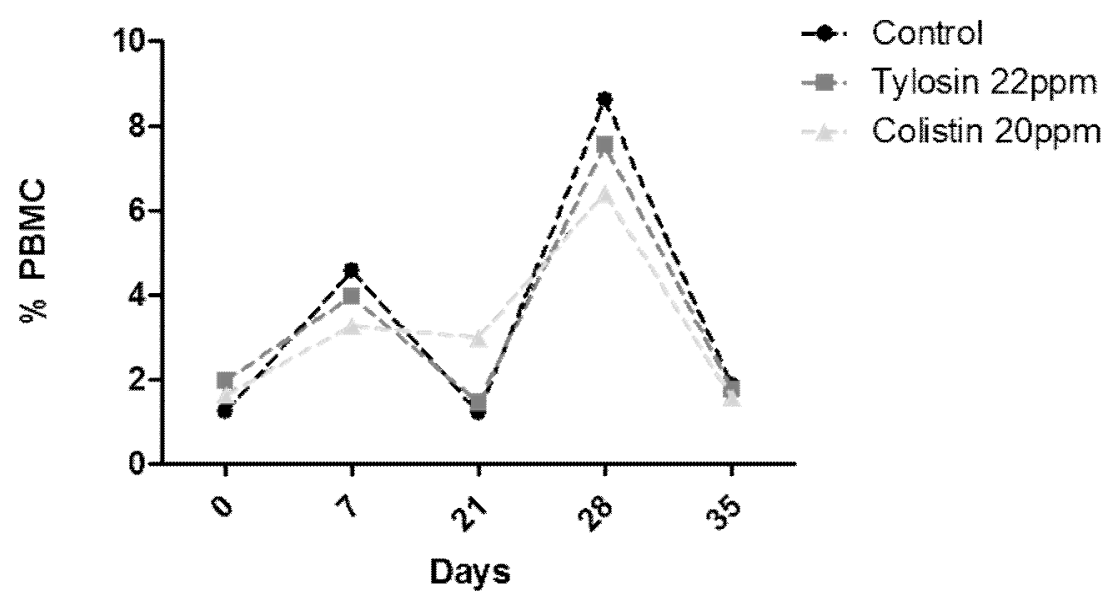


Figure 4. Percentage of circulating $\mathrm{Bu}-1^{+}$cells (B-lymphocytes) in relation to peripheral blood mononuclear cells (PBMC). Nursery pigs were fed a basal diet without antibiotics (control) or with $20 \mathrm{ppm}$ of colistin or $22 \mathrm{ppm}$ of tylosin. Blood was collected for PBMC immune cell typing at the time of weaning (day 0) and 7, 21, 28, and 35 days later. The immunophenotype of PBMC was determined by flow cytometry. Statistical differences at a specific date are indicated by different letters with the same color as the corresponding group. Data were analyzed by two-way ANOVA $(\mathrm{P}<0.05)$.

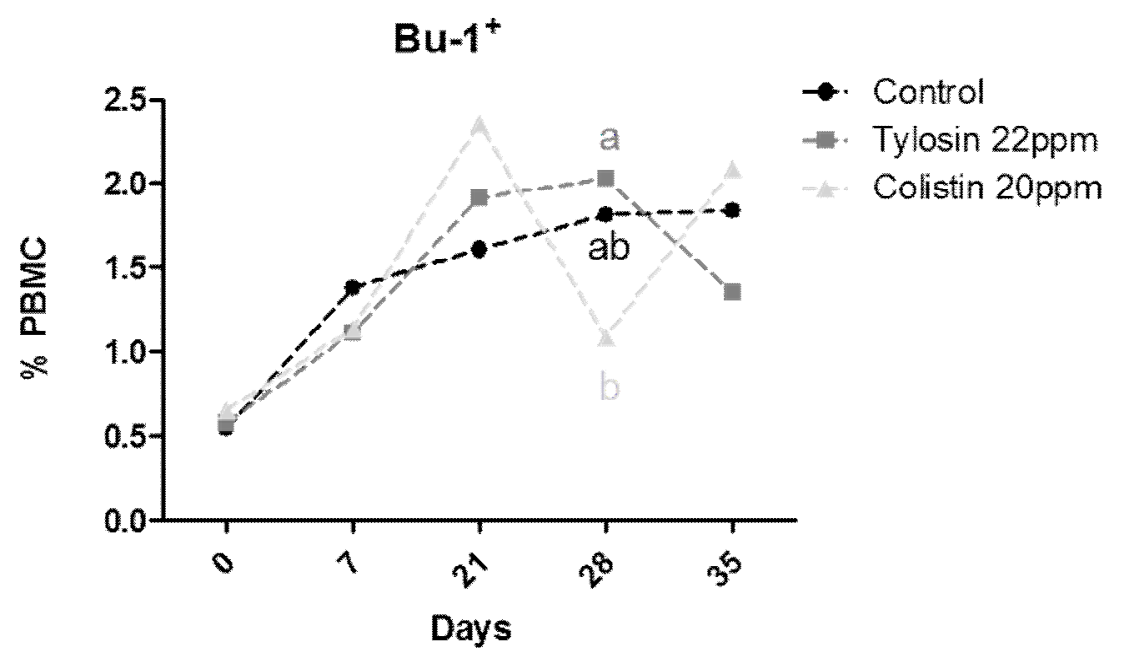

On d28, the control group showed a higher percentage of $\mathrm{CD} 4+\mathrm{CD} 8+\mathrm{T}$ cells relative to the tylosin group, while the colistin group showed similar percentages to the former (Figure 5). Doublepositive $\mathrm{T}$ cells (CD4+CD8+) are a specific immune characteristic of pigs. Many authors believe that they are activated memory cells (ZUCKERMANN; HUSMANN, 1996), capable of eliciting humoral immune responses (SAALMÜLLER et al., 2002). In a study with calves, the percentages of circulating CD4 and CD8 T cells were modulated with the use of tylosin (SZYMAÑSKA-CZERWIÑSKA et al., 2009). The double-positive population is rare in cattle, but the results of the present study with CD4+CD8+ T cells (Figure 5) may be consistent with the findings of the study of Szymañska-Czerwiñska et al. (2009), which analyzed the individual CD4 and CD8 populations. In the present study, no differences in the percentages of the individual CD4 or CD8 T cells were observed (Figures 1 and 2); however, double-positive $\mathrm{CD} 4+\mathrm{CD} 8+\mathrm{T}$ cells decreased when tylosin was used as a feed additive. This effect may be due to the effect of tylosin on macrophages, which in turn control the subsequent immune response by producing cytokines (SZYMAÑSKA-CZERWIÑSKA et al., 2009). Although no difference was seen concerning the circulating numbers of monocytes, tylosin could have had an effect on cytokine production by these cells, or could even have altered local (intestinal, for instance) macrophage populations, which can control circulating lymphocytes. Tylosin is indeed capable of altering the proliferative capacity of immune cells, thus explaining some of the findings of the present study (BABA et al., 1998).

On $\mathrm{d} 28$, the CD4:CD8 ratio was higher in the tylosin group as compared to the colistin group. The lowest ratio was obtained in the control group (Figure 6). Tylosin promotes the production of pro-inflammatory cytokines, such as interleukin 1 (IL-1), interleukin 2 (IL-2), interferons (IFNs), and tumor necrosis factor alpha (TNF $\alpha)$. SzymañskaCzerwiñska et al. (2009) showed that tylosin increased the percentage of $\mathrm{CD}^{+}$in calves, which may explain the higher CD4:CD8 ratio obtained in the present study in the piglets fed tylosin. In other species, it has been suggested that this ratio is indicative of immune competence (BRIDLE et al., 2006). 
Figure 5. Percentage of circulating double-positive $\mathrm{CD} 4^{+} \mathrm{CD} 8^{+} \mathrm{T}$ cells in relation to peripheral blood mononuclear cells (PBMC). Nursery pigs were fed a basal diet without antibiotics (control) or with $20 \mathrm{ppm}$ of colistin or $22 \mathrm{ppm}$ of tylosin. Blood was collected for PBMC immune cell typing at the time of weaning (day 0) and 7, 21, 28, and 35 days later. The immunophenotype of PBMC was determined by flow cytometry. Statistical differences at a specific date are indicated by different letters with the same color as the corresponding group. Data were analyzed by two-way ANOVA $(\mathrm{P}<0.05)$.

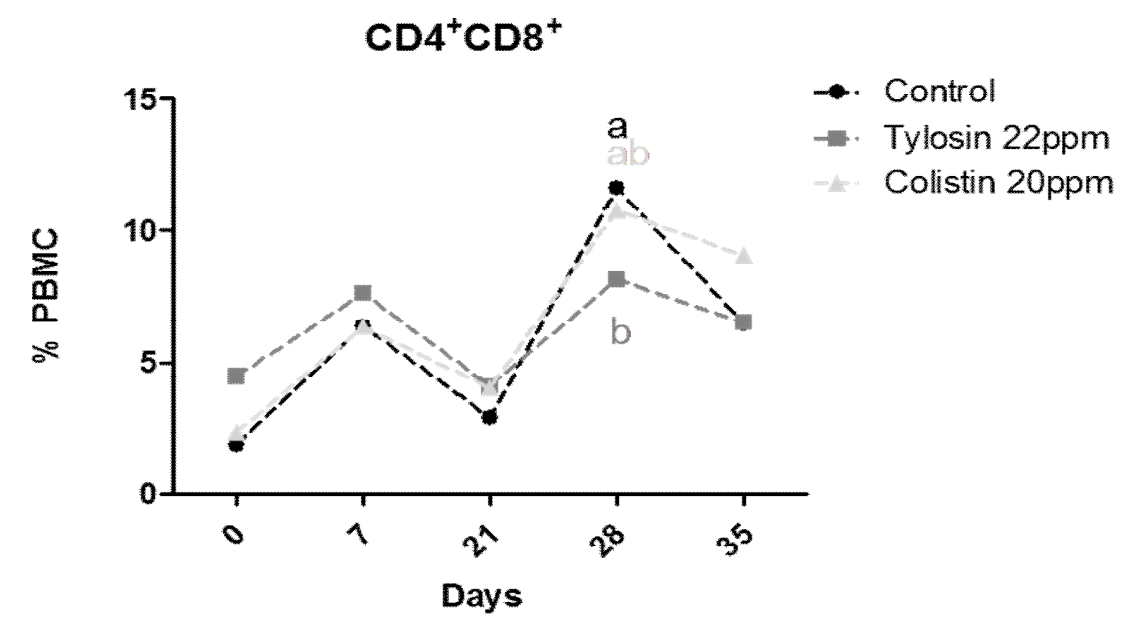

Figure 6. Percentage of circulating CD4 to CD8 T cell ratio. Nursery pigs were fed a basal diet without antibiotics (control) or with $20 \mathrm{ppm}$ of colistin or with $22 \mathrm{ppm}$ of tylosin. Blood was collected for PBMC immune cell typing at the time of weaning (day 0) and 7,21, 28, and 35 days later. The immunophenotype of PBMC was determined by flow cytometry. Statistical differences at a specific date are indicated by different letters with the same color as the corresponding group. Data were analyzed by two-way ANOVA $(\mathrm{P}<0.05)$.

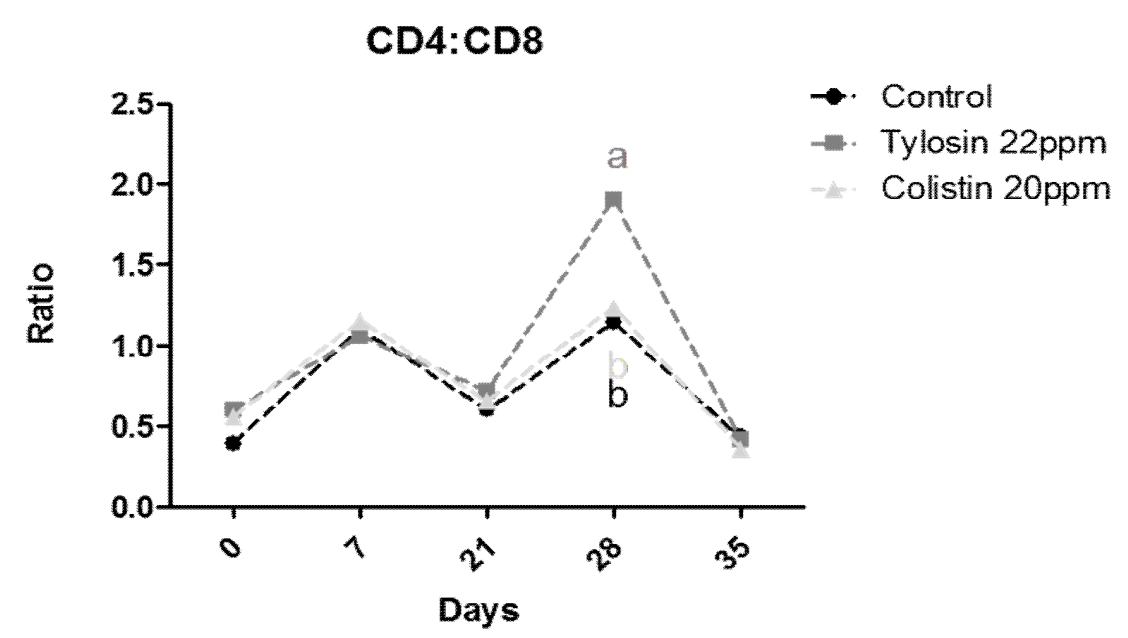

The fluctuations in the immune cells were accompanied by an improvement in the health status of the treated groups. Two interpretations can be derived from this observation, either the immune changes are causes or consequences of the improved diarrhea status. The additives may have altered the immune stimulation by removing environmental to an improved immune response, which itself suppressed the environmental pressure. The actual effect of these immune changes on the health status of the animals cannot be determined with the data presented here, and should be further clarified in the future with the use of experimental infections and long-term studies. 


\section{Conclusions}

The inclusion of colistin and tylosin in the diet of nursery piglets as feed additives significantly increased average daily feed intake, resulting in a higher body weight at the end of the experimental period. Colistin and tylosin also promoted a significant reduction in the incidence of diarrhea, which probably contributed to the improved performance observed.

Colistin and tylosin modulated the piglet's immune response, particularly on $\mathrm{d} 28$, changing the percentage of circulating B lymphocytes, $\mathrm{CD} 4^{+} \mathrm{CD} 8^{+} \mathrm{T}$ cells, and the $\mathrm{CD} 4: \mathrm{CD} 8$ ratio. It is important to observe that the immune changes were linked to a clinical finding (diarrhea), regardless of whether they were causative or consequential. The different mechanisms of action of both additives may account for the varying immune effects seen after using the additives.

\section{References}

BABA, T.; YAMASHITA, N.; KODAMA, H.; MUKAMOTO, M.; ASADA, M.; NAKAMOTO, K.; NOSE, Y.; McGRUDER, E. D. Effect of tylosin tartrate (Tylan Soluble) on cellular immune responses in chickens. Poultry Science, Savoy, v. 77, n. 9, p. 13061311, 1998.

BAUER, E.; WILLIAMS, B. A.; SMIDT, H.; VERSTEGEN, M. W. A.; MOSENTHIN, R. Influence of the gastrointestinal microbiota on development of the immune system in young animals. Current Issues in Intestinal Microbiology, Wymondham, v. 7, n. 2, p. 3551, 2006.

BLUM, S.; SCHIFFRIN, E. J. Intestinal microflora and homeostasis of the mucosal immune response: implications for probiotic bacteria? Current Issues in Intestinal Microbiology, Wymondham, v. 4, n. 2. p. 5360, 2003.

BOSI, P.; MERIALDI, G.; SCANDURRA, S.; MESSORI, S.; BARDASI, L.; NISI, I.; RUSSO, D.; CASSINI, L.; TREVISI, P. Feed supplemented with 3 different antibiotics improved food intake and decreased the activation of the humoral immune response in healthy weaned pigs but had differing effects on intestinal microbiota. Journal of Animal Science, Champaign, v. 89, n. 12, p. 4043-4053, 2011.
BOUSKRA，D.; BRÉZILLON，C.; BÉRARD， M.; WERTS, C.; VARONA, R.; BONECA, I. G.; EBERL, G. Lymphoid tissue genesis induced by commensals through NOD1 regulates intestinal homeostasis. Nature, London, v. 456, n. 7221, p. 507-510, 2008.

BRIDLE, B. W.; JULIAN, R.; SHEWEN, P. E.; VAILLANCOURT, J. P.; KAUSHIK, A. K. T lymphocyte subpopulations diverge in commercially raised chickens. Canadian Journal of Veterinary Research, Ottawa, v. 70, n. 3, p. 183-190, 2006.

BUTAYE, P.; DEVRIESE, L. A.; HAESEBROUCK, F. Antimicrobial growth promoters used in animal feed: effects of less well known antibiotics on Gram-positive bacteria. Clinical Microbiology Reviews, Washington DC, v. 16, n. 2, p. 175-188, 2003.

CAO, X. Y.; DONG, M.; SHEN, J. Z.; WU, B. B.; WU, C. M.; DU, X. D.; WANG, Z.; QI, Y. T.; LI, B. Y. Tilmicosin and tylosin have anti-inflammatory properties via modulation of COX-2 and iNOS gene expression and production of cytokines in LPS-induced macrophages and monocytes. International Journal of Antimicrobial Agents, London, v. 27, n. 5, p. 431-438, 2006.

CANADIAN COUNCIL ON ANIMAL CARE - CCAC. Guide to the care and use of experimental animals. $2^{\text {th }}$ ed. Ontario: CCAC, 1993. v. 1, 298 p.

COLLIER, C. T.; SMIRICKY-TJARDES, M. R.; ALBIN, D. M.; WUBBEN, J. E. V.; GABERT, M.; DEPLANCKE, B.; BANE, D.; ANDERSON, D. B.; GASKINS, H. R. Molecular ecological analysis of porcine ileal microbiota responses to antimicrobial growth promoters. Journal Animal Science, Champaign, v. 81, n. 12, p. 3035-3045, 2003.

COSTA, L. B.; TSE, M. L. P.; MIYADA, V. S. Extratos vegetais como alternativas aos antimicrobianos promotores de crescimento para leitões recémdesmamados. Revista Brasileira de Zootecnia, Viçosa, MG, v. 36, n. 3, p. 589-595, 2007.

CROMWELL, G. L. Why and how antibiotics are used in swine production. Animal Biotechnology, Urbana, v. 13, n. 1, p. 7-27, 2002.

DIBNER, J. J.; BUTTIN, P. Use of organic acids as a model to study the impact of gut microflora on nutrition and metabolism. The Journal of Applied Poultry Research, Oxford, v. 11, n. 4, p. 453-463, 2002.

DIBNER, J. J.; RICHARDS, J. D. Antibiotic growth promoters in agriculture: history and mode of action. Poultry Science, Savoy, v. 84, n. 4, p. 634-643, 2005.

FERNANDES FILHO, T.; FÁVARO, J. R. C.; INGBERMAN, M.; BEIRÃO, B. C.; INOUE, A.; GOMES, L.; CARON, L. F. Effect of spray Escherichia 
coli vaccine in the immunity of poultry. Avian Diseases, Florida, v. 57, n. 3, p. 671-676, 2013.

GAGGİA, F.; MATTARELLI, P.; BIAVATI, B. Probiotics and prebiotics in animal feeding for safe food production: a review. International Journal of Food Microbiology, Torino, v. 141, n. 1, p. S15-S28, 2010.

GAVIOLI, D. F. Efeito de promotores de crescimento para suínos sobre o desempenho zootécnico, a qualidade intestinal e a eficiência da biodigestão dos dejetos. Semina: Ciências Agrárias, Londrina, v. 34, n. 6, p. 3983-3998, 2013. Suplemento 2.

GOMES, P. C.; SOBESTIANSKY, J.; BRITO, J. R. F.; BELLAVER, C.; PACHECO, C. R. V. M. Colistina $e$ zinco bacitracina como aditivos para suínos. Concórdia: Embrapa Suínos e Aves - CNPSA, 1981. 3 p. (Comunicado técnico, 18).

GORIS, H.; DAENEN, S.; HALIE, M. R.; VAN DER WAAIJ, D. Effect of intestinal flora modulation by oral polymyxin treatment on hemopoietic stem cells kinetics in mice. Acta Haematologica, Basel, v. 76, n. 1, p. 44-49, 1986.

GRUYS, E.; TOUSSAINT, M. J. M.; NIEWOLD, T. A.; KOOPMANS, S. J.; VAN DIJK, E.; MELOEN, R. H. Monitoring health by values of acute phase proteins. Acta Histochemica, Bologna, v. 108, n. 3, p. 229-232, 2006.

HARDY, B. The issue of antibiotic use in the livestock industry: what have we learned? Animal Biotechnology, Urbana, v. 13, n. 1, p. 129-147, 2002.

HEO, J. M.; OPAPEJU1, F. O.; PLUSKE, J. R.; KIM, J. C.; HAMPSON, D. J.; NYACHOTI, C. M. Gastrointestinal health and function in weaned pigs: a review of feeding strategies to control post-weaning diarrhoea without using in-feed antimicrobial compounds. Journal of Animal Physiology and Animal Nutrition, Berlin, v. 97, n. 2, p. 207-237, 2013.

HOLMAN, D. B.; CHENIER, M. R. Impact of subtherapeutic administration of tylosin and chlortetracycline on antimicrobial resistance in farrowto-finish swine. FEMS Microbiology Ecology, Oxford, v. 85, n. 1, p. 1-13, 2013.

JUKES, T. H. Antibiotics in animal feeds and animal production. Bioscience, Washington, v. 22, n. 9, p. 526534, 1972.

KIM, H. B.; BOREWICZ, K.; WHITE, B. A.; SINGER, R. S.; SREEVATSAN, S.; TU, Z. J.; ISAACSON, R. E. Microbial shifts in the swine distal gut in response to the treatment with antimicrobial growth promoter, tylosin. Proceedings of the National Academy of Sciences, Washington D.C., v. 109, n. 38, p. 15485-15490, 2012.
KIMURA, K.; MCCARTNEY, A. L.; MCCONNELL, M. A.; TANNOCK, G. W. Analysis of fecal populations of bifidobacteria and lactobacilli and investigation of the immunological responses of their human hosts to the predominant strains. Applied and Environmental Microbiology, Washington D.C., v. 63, n. 9, p. 33943398, 1997.

KONSTANTINOV, S. R.; AWATI, A. A.; WILLIAMS, B. A.; MILLER, B. G.; JONES, P.; STOKES, C. R.; AKKERMANS, A. D.; SMIDT, H.; DE VOS, W. M. Postnatal development of the porcine microbiota composition and activities. Environmental Microbiology, Oxford, v. 8, n. 7, p. 1191-1199, 2006.

KONSTANTINOV, S. R.; FAVIER, C. F.; ZHU, W. Y; WILLIAMS, B. A.; KLÜß, J.; SOUFFRANT, W. B.; DE VOS, W. M.; AKKERMANS, A. D. L.; SMIDT, H. Microbial diversity studies of the porcine gastrointestinal ecosystem during weaning transition. Animal Research, Les Ulis, v. 53, n. 4, p. 317-324, 2004.

LALLÈS, J. P.; BOSI, P.; SMIDT, H.; STOKES, C. R. Nutritional management of gut health in pigs around weaning. Proceedings of the Nutrition Society, London, v. 66, n. 2, p. 260-268, 2007.

LARSSON, A. E.; MELGAR, S.; REHNSTRÖM, E.; MICHAËLSSON, E.; SVENSSON, L.; HOCKINGS, P.; OLSSON, L. E. Magnetic resonance imaging of experimental mouse colitis and association with inflammatory activity. Inflammatory Bowel Diseases, Hoboken, v. 12, n. 6, p. 478-485, 2006.

LIMA, G. J. M. M.; MORÉS, N.; SANCHES, R. L. As diarreias nutricionais na suinocultura. Acta Scientiae Veterinariae, Porto Alegre, v. 37, n. 1, p. s17-s30, 2009.

LOVATTO, P. A.; OLIVEIRA, V.; HAUPTLI, L.; HAUSCHILD, L.; CAZARRÉ, M. M. Alimentação de leitões na creche com dietas sem aditivos antimicrobianos, com alho (Allium sativum, L.) ou colistina. Ciência Rural, Santa Maria, v. 35, n. 3, p. 656-659, 2005.

LUNA, U. V.; CARAMORI JÚNIOR, J. G.; CORRÊA, G. S. S.; KIEFER, C.; SOUZA, M. A.; VIEITES, F. M.; CRUZ, R. A. S.; ASSIS, S. D. Mananoligossacarídeo e ß-glucano em dietas de leitões desmamados. Arquivo Brasileiro de Medicina Veterinária e Zootecnia, Belo Horizonte, v. 67, n. 2, p. 591-599, 2015.

MARCOLLA, C. S.; RIBEIRO, A. M. L. Efeitos do fornecimento de dietas pré-desmame para leitões: uma revisão. Boletim de Indústria Animal, Nova Odessa, v. 72, n. 1, p. 77-90, 2015.

MARTINEZ, J. F.; AMORIM, A. B.; FARIA, D. E.; NAKAGI, V. S.; SARTORI, M. M. P.; MARQUES, M. F. Palatabilizantes em dietas de leitões recém-desmamados. 
Arquivo Brasileiro de Medicina Veterinária e Zootecnia, Belo Horizonte, v. 66, n. 4, p. 1207-1215, 2014.

MENDES, C. A. C.; BURDMANN, E. A. Polimixinas: revisão com ênfase na sua nefrotoxicidade. Revista $d a$ Associação Médica Brasileira, São Paulo, v. 55, n. 6, p. 752-759, 2009.

MINISTÉRIO DA AGRICULTURA, PECUÁRIA E ABASTECIMENTO - MAPA. Tabela de aditivos antimicrobianos, anticoccidianos e agonistas com uso autorizado na alimentação animal. Brasília: MAPA, 2014. Disponível em: <http://www.agricultura.gov.br/ animal/alimentacao/aditivos/aditivos-autorizados>. Acesso em: 25 fev. 2015.

MODESTO, M.; D’AIMMO, M. R.; STEFANINI, I.; TREVISI, P.; DE FILIPPI, S.; CASINI, L.; MAZZONI, M.; BOSI, P.; BIAVATI, B. A novel strategy to select Bifidobacterium strains and prebiotics as natural growth promoters in newly weaned pigs. Livestock Science, Amsterdam, v. 122, n. 2, p. 248-258, 2009.

MORÉS, N.; MORENO, A. M. Síndrome da diarreia pós-desmame. In: SOBESTIANSKY, J.; BARCELOS, D. E. S. N. (Ed.). Doenças dos suínos. Goiânia: Cânone Editorial, 2007. p. 203-205.

NATIONAL RESEARCH COUNCIL - NRC. Nutrient requirements of swine. $11^{\text {th }}$ ed. rev. Washington, D. C.: National Academic Press, 2012.

NIEWOLD, T. A. The nonantibiotic anti-inflammatory effect of antimicrobial growth promoters, the real mode of action? A hypothesis. Poultry Science, Savoy, v. 86, n. 4, p. 605-609, 2007.

NORCIA, L. J.; SILVIA, A. M.; HAYASHI, S. F. Studies on timekill kinetics of different classes of antibiotics against veterinary pathogenic bacteria including Pasteurella, Actinobacillus and Escherichia coli. Journal of Antibiotics, Tokyo, v. 52, n. 1, p. 52-60, 1999.

PALERMO NETO, J. Resíduos de atimicrobianos em alimentos. Revista do Conselho Federal de Medicina Veterinária-CFMV, Brasília, v. 7, n. 22, p. 65-71, 2001.

PLUSKE, J. R. Feed- and feed additives-related aspects of gut health and development in weanling pigs. Journal of Animal Science and Biotechnology, Beijing, v. 4, n. 1, p. 1-7, 2013.

PUTAALA, H.; BARRANGOU, R.; LEYER, G. J.; OUWEHAND, A. C.; HANSEN, E. B.; ROMERO, D. A.; RAUTONEN, N. Analysis of the human intestinal epithelial cell transcriptional response to Lactobacillus acidophilus, Lactobacillus salivarius, Bifidobacterium lactis and Escherichia coli. Beneficial Microbes, Wageningen, v. 1, n. 3, p. 283-295, 2010.
SAALMÜLLER, A.; WERNER, T.; FACHINGER, V. T-helper cells from naive to committed. Veterinary Immunology and Immunopathology, Amsterdam, v. 87, n. 3-4, p. 137-145, 2002.

SAVOINI, G.; BONTEMPO, V.; CHELI, F.; BALDI, A.; SALA, V.; MANCIN, G.; AGAZZI, A.; DELL'ORTO, V. Alternative antimicrobials in the nutrition of postweaning piglets. Veterinary Record, London, v. 151, n. 19, p. 577580, 2002.

SBARDELLA, M. $\beta$-ácidos do lúpulo (Humulus lupulus) como melhorador de desempenho de leitões em fase de creche. 2014. Tese (Doutorado em Ciências) - Escola Superior de Agricultura Luiz de Queiroz. Universidade de São Paulo, Piracicaba.

SILVA, C. A.; BRIDI, A. M.; CASTRO-GOMEZ, R. J. H.; BENITEZ DA SILVA, C. R.; MENEGUCCI, C. G.; CARVALHO, B. B. Uso de probiótico e de antibióticos na alimentação de leitões em fase de creche. Semina: Ciências Agrárias, Londrina, v. 28, n. 4, p. 739-746, 2007.

SPINOSA, H. S. Antibióticos: aminoglicosídeos, polimixinas, bacitracina e vancomicina. In: SPINOSA, H. S.; GÓRNIAK, S. L.; BERNARDI, M. M. (Ed.). Farmacologia aplicada à medicina veterinária. 4 . ed. Rio de Janeiro: Guanabara Koogan, 2006a. p. 472-476.

Antibióticos: macrolídeos, lincosamidas, rifaminas, fosfomicina e novobiocina. In: SPINOSA, H. S.; GÓRNIAK, S. L.; BERNARDI, M. M. (Ed.). Farmacologia aplicada à medicina veterinária. 4. ed. Rio de Janeiro: Guanabara Koogan, 2006b. p. 482-486.

SZYMAÑSKA-CZERWIÑSKA, M.; BEDNAREK, D.; ZDZISIÑSKA, B; KANDEFER-SZERSZEÑ, M. Effect of tylosin and prebiotics on the level of cytokines and lymphocyte immunophenotyping parameters in calves. Central European Journal of Immunology, Warsaw, v. 34, n. 1, p. 1-6, 2009.

THOMSSON, A.; RANTZER, D.; BOTERMANS, J.; SVEDSEN, J. The effect of feeding system at weaning on performance, health and feeding behaviour of pigs of different sizes. Acta Agriculturae Scandinavica, Section A-Animal Science, London, v. 58, n. 2, p. 78-83, 2008.

TORRALLARDONA, D.; CONDE, M. R.; BADIOLA, I.; POLO, J.; BRUFAU, J. Effect of fishmeal replacement with spray-dried animal plasma and colistin on intestinal structure, intestinal microbiology, and performance of weanling pigs challenged with Escherichia coli K99. Journal of Animal Science, Champaign, v. 81, n. 5, p. 1220-1226, 2003. 
UTIYAMA, C. E.; OETTING, L. L.; GIANI, P. A.; RUIZ, U. S.; MIYADA, V. S. Efeitos de antimicrobianos, prebióticos, probióticos e extratos vegetais sobre a microbiota intestinal, a frequência de diarreia e o desempenho de leitões recém-desmamados. Revista Brasileira de Zootecnia, Viçosa, MG, v. 35, n. 6, p. 23592367, 2006.

VAN LUNEN, T. A. Growth performance of pigs fed diets with and without tylosin phosphate supplementation and reared in a biosecure all-in all-out housing system. Canadian Veterinary Journal, Guelph, v. 44, n. 7, p. 571576, 2003.

VARCOE, J. J.; KREJCAREK, G.; BUSTA, F.; BRADY, L. Prophylactic feeding of Lactobacillus acidophilus NCFM to mice attenuates overt colonic hyperplasia. Journal of Food Protection, Des Moines, v. 66, n. 3, p. 457-465, 2003.
YAN, L.; LEE, J. H.; MENG, Q. W.; KIM, I. H. Evaluation of the Anion ${ }^{\circledR}$ supplementation on growth performance, nutrient digestibility, blood characteristics and faecal noxious gas content in weaning pigs. Journal of Applied Animal Research, Abingdon, v. 39, n. 1, p. 3640, 2011.

YUAN, S. L.; PIAO, X. S.; LI, D. F.; KIM, S. W.; LEE, H. S.; GUO, P. F. Effects of dietary Astragalus polysaccharide on growth performance and immune function in weaned pigs. Animal Science, Liverpool, v. 82, n. 4, p. 501-507, 2006.

ZUANON, J. A. S.; FONSECA, J. B.; ROSTAGNO, H. S.; ALMEIDA E SILVA, M. Efeito de promotores de crescimento sobre o desempenho de frangos de corte. Revista Brasileira de Zootecnia, Viçosa, MG, v. 27, n. 5, p. 999-1005, 1998.

ZUCKERMANN, F. A.; HUSMANN, R. J. Functional and phenotypic analysis of porcine peripheral blood CD4/CD8 double-positive T cells. Immunology, London, v. 87 , n. 3 , p. $500-512,1996$. 